\title{
Numerical analysis of phenotypic properties, genomic fingerprinting, and multilocus sequence analysis of Bradyrhizobium strains isolated from root nodules of Lembotropis nigricans of the tribe Genisteae
}

\author{
Magdalena Wójcik $^{1} \cdot$ Michał Kalita $^{1}(\mathbb{D}) \cdot$ Wanda Małek ${ }^{1}$
}

Received: 8 April 2019 / Accepted: 31 May 2019/Published online: 15 June 2019

(C) The Author(s) 2019

\begin{abstract}
Purpose The aim of this study was to estimate the level of genomic and phenotypic diversity as well as the genus and species position of bacterial strains isolated from root nodules of Lembotropis nigricans (family Fabaceae).

Methods The genomic diversity of studied L. nigricans nodule symbionts was examined by using BOX-PCR and AFLP (amplified fragment length polymorphism) fingerprinting techniques. To assign bacteria to the genus, numerical analysis of phenotypic features and comparative analysis of $16 \mathrm{~S}$ rDNA sequences were performed. The comparative analysis of combined $a t p D$, dnaK, gyrB, and $r p o B$ gene sequences (multilocus sequence analysis, MLSA) was used to determine the most closely related species to the studied bacteria.

Results Both BOX-PCR and AFLP techniques revealed a high level of genomic heterogeneity of L. nigricans nodulators. Among 33 studied bacteria, 32 genotypes were delineated by the AFLP method and 27 genotypes were identified by the BOX-PCR fingerprinting. The numerical analysis of 86 phenotypic characteristics of $L$. nigricans nodule isolates and reference rhizobia showed that studied bacteria belong to the genus Bradyrhizobium. Affiliation of $L$. nigricans nodule isolates to the genus Bradyrhizobium was supported by comparative analysis of $16 \mathrm{~S}$ rDNA sequences and the concatenation of atpD, dnaK, gyrB, and rpoB gene sequences. MLSA indicated also that L. nigricans microsymbionts are members of Bradyrhizobium japonicum.

Conclusion L. nigricans root nodule symbionts are members of Bradyrhizobium japonicum and exhibit high phenotypic and genomic diversity important for their survival in soil.
\end{abstract}

Keywords AFLP · BOX-PCR · Bradyrhizobium $\cdot$ Genisteae $\cdot$ Lembotropis nigricans $\cdot$ Multilocus sequence analysis

Magdalena Wójcik and Michał Kalita contributed equally to this work.

The GenBank accession numbers for sequences generated in this study are as follows: MK183761-MK183771 (16S rRNA), MK202810MK202820 (atpD), MK202821-MK202831 (dnaK), MK202832MK202842 (gyrB), MK202843-MK202853 (rpoB).

Electronic supplementary material The online version of this article (https://doi.org/10.1007/s13213-019-01491-6) contains supplementary material, which is available to authorized users.

Michał Kalita

michal.kalita@umcs.pl

1 Department of Genetics and Microbiology, Maria Curie Sklodowska University, Akademicka 19, 20-033 Lublin, Poland

\section{Introduction}

Rhizobia are soil-inhabiting bacteria capable of establishing nitrogen-fixing symbiosis with plant species of the family Fabaceae. Genisteae encompassing more than 600 species distributed among 25 genera is one of the largest tribes within the legume family (Cardoso et al. 2013). There are published reports on the phylogeny and taxonomy of bacterial strains isolated from root nodules of 77 plant species of the tribe Genisteae. Based on these reports, it was concluded that the strains of the genus Bradyrhizobium form a predominant group infecting Genisteae legumes (Stępkowski et al. 2018). Still, there are no data available on rhizobia of 14 Genisteae genera. One of such plant genus is Lembotropis comprising two species: Lembotropis nigricans (L. Griseb.) and Lembotropis emeriflora (Rchb.). L. nigricans (black broom) is distributed in Central and Southeastern Europe; however, its exact range is hard to estimate since it has been grown as an 
ornamental shrub for many years and it can currently be found in many areas as a wild plant (Petrowicz 1981). Although it has been previously demonstrated that $L$. nigricans produces cylindrical root nodules (Lotocka et al. 2012), the bacteria residing in these structures have not been analyzed for their phenotypic properties, genomic diversity, and taxonomic affiliation.

Polyphasic taxonomy, which integrates all available genotypic, phenotypic, and phylogenetic information, has been widely used for identification and classification of bacteria since the 1970s (Vandamme and Peeters 2014). Numerical analysis of phenotypic and genotypic features allows differentiation of closely related bacteria and preliminary determination of the genus position of microorganisms. The PCR fingerprinting techniques such as BOX-PCR and AFLP are often used for the assessment of the genomic diversity of rhizobia isolated from root nodules of different legume species (Kalita and Małek 2006; Liu et al. 2011; Gnat et al. 2015; Xu et al. 2016; Wdowiak-Wróbel et al. 2017; Chidebe et al. 2018).

Since the 1990s, the phylogenetic studies of root nodule isolates have been based mainly on partial or complete $16 \mathrm{~S}$ rDNA sequences (Young et al. 1991; Vinuesa et al. 1998). Since then, many studies have demonstrated that the diversity in the 16S rRNA sequences of rhizobia is low and distinguishes species poorly (Menna et al. 2009; Delamuta et al. 2013). Due to the limitations of the $16 \mathrm{~S}$ rRNA gene analysis, protein-encoding genes with evolution rates faster than that of $16 \mathrm{~S}$ rDNA, but conserved sufficiently to retain genetic information, have been proposed as alternative phylogenetic markers. atpD, dnaK, glnII, gyr $B$, recA, and rpoB are examples of housekeeping genes that are frequently used in tracing the evolutionary history of bacteria (Gaunt et al. 2001; Stępkowski et al. 2003; Vinuesa et al. 2005; Rivas et al. 2009; Kalita and Małek 2017; Huang et al. 2018).

In this study, we examined the genus position and evolutionary history of L. nigricans root nodule isolates using numerical analysis of phenotypic properties and comparative sequence analysis of $16 \mathrm{~S}$ rRNA, atpD, dnaK, gyrB, and $r p o B$ genes. L. nigricans symbionts were also examined for BOX-PCR and AFLP patterns to study their genomic relationship and diversity.

\section{Materials and methods}

\section{Bacterial strains}

The strains used in this study and their origin are listed in Supplementary Table S1. Root nodules of L. nigricans were collected from plants growing at a single location in southeast Poland (51 $\left.08^{\prime} 47.2^{\prime \prime} \mathrm{N} 23^{\circ} 24^{\prime} 43.3^{\prime \prime} \mathrm{E}\right)$. The L. nigricans population occupied area of approximately $50 \mathrm{~m}^{2}$. Ten randomly selected individual plants from five distinct patches were used for root nodule collection. The rhizobia studied were isolated from root nodules with the standard procedure (Kalita and Małek 2004). Yeast extract mannitol medium (YEM) was routinely used for cultivation of the rhizobia at $28{ }^{\circ} \mathrm{C}$. The strains were stored as source cultures on YEM slants at $4^{\circ} \mathrm{C}$.

\section{Phenotypic characterization and numerical analysis of phenotypic properties}

L. nigricans nodule isolates were examined for cell morphology, motility, and generation time according to a procedure described earlier by Wdowiak and Małek (2000). Their phenotypic properties, i.e., temperature and $\mathrm{pH}$ growth ranges, $\mathrm{NaCl}$ tolerance, acid and alkali production in YEM agar supplemented with bromothymol blue as a $\mathrm{pH}$ indicator, utilization of different compounds as sole carbon and nitrogen sources, resistance to antibiotics and dyes, reaction in litmus milk, activity of urease, catalase, $\beta$-galactosidase, phosphatase, nitrate reductase, cytochrome oxidase, $\beta$-D-glucosidase, and peroxidase, synthesis of indole, melanin, and indole-3acetic acid (IAA), adsorption of Congo red and Calcofluor, and precipitation of calcium glycerophosphate were determined according to Wdowiak and Małek (2000). The utilization of various compounds as a sole carbon source was studied in modified Bergersen's synthetic medium (BS medium) in which mannitol was replaced by the tested compound. The utilization of various compounds as a sole nitrogen source was examined in the same BS medium with the tested substance instead of $\mathrm{NH}_{4} \mathrm{Cl}$. All phenotypic tests were done in triplicate and repeated two times. The results were scored after 5 days for fast-growing strains and 7-10 days for slowgrowing strains (Garrity et al. 2005).

For numerical analysis, the phenotypic features of the rhizobia studied were coded in the binary system. Next, the simple matching similarity coefficient (SM) of each strain pair was estimated and a similarity matrix was generated (Sneath and Sokal 1973). Based on the similarity matrix, clustering analysis was performed with the unweighted pair group method with arithmetic mean (UPGMA) using the NTSYSpc software package (Exeter Software).

\section{Isolation of total genomic DNA}

For DNA isolation, bacteria were grown in $30 \mathrm{ml}$ of liquid YEM medium for $4-5$ days at $28^{\circ} \mathrm{C}$. DNA was extracted and purified according to the method proposed by Pitcher et al. (1989) as described elsewhere (Kalita and Małek 2004).

\section{BOX-PCR, AFLP, and data analysis}

The primers and PCR cycling conditions used in the BOXPCR and AFLP analyses are listed in Supplementary 
Table S2. The AFLP procedure was done as described by Tyrka (2002) with some small modifications as described elsewhere (Kalita and Małek 2006). Each reaction was repeated three times on the same DNA matrix. Only informative and reproducible products of the genomic fingerprinting reactions were analyzed. The PCR products were separated in $1.5 \%$ agarose gel, stained with ethidium bromide, and visualized under UV light. The DNA profiles yielded by the BOXPCR and AFLP methods were analyzed using BIO-GEN program version 11.01 (Vilber-Lourmat). The strains were grouped by the Nei and Li coefficient (Nei and Li 1979) and the dendrogram was constructed using the UPGMA method.

\section{Amplification and sequencing of 165 rRNA, atpD, $d n a K, g y r B$, and $r p o B$ genes}

The primers and PCR amplification conditions used in this study are listed in Supplementary Table S2. All PCR amplification reactions were carried out with ReadyMix ${ }^{\mathrm{TM}} \mathrm{Taq}$ PCR Reaction Mix (Sigma) according to the manufacturer's recommendations. DNA-free water was used in negative PCR controls. Genomic DNA of B. japonicum $\mathrm{USDA}^{\mathrm{T}}$ was used as a template in positive PCR controls. The amplified products were purified with Clean-Up or Gel-Out purification columns (A\&A Biotechnology) and sequenced with the BigDye Terminator Cycle sequencing kit (Thermo Fisher Scientific) using the 3500 Genetic Analyzer according to the manufacturer's procedures.

\section{Phylogenetic analysis}

The sequences yielded in this study were compared to the nucleotide sequences from GenBank database using the BLAST program (Altschul et al. 1990). Since all the sequences were most similar to the sequences of the genus Bradyrhizobium strains, only reference bradyrhizobia were included for further phylogenetic analyses. All phylogenetic analyses were conducted in MEGA 7 (Kumar et al. 2016) as follows. Multiple sequence alignments were constructed and the resulting alignments were corrected manually. To obtain the same number of analyzed positions in the alignment, longer sequences were truncated. As a result, 1228, 429, 204, 563 , and 452 nucleotide positions were analyzed for the $16 \mathrm{~S}$ rRNA, atpD, dnaK, gyrB, and $r p o B$ genes, respectively. The maximum likelihood (ML) method was used to reconstruct the phylogeny of the analyzed genes. jModelTest (Darriba et al. 2012) was used to choose the best-fit evolutionary model for each studied gene. To determine the degree of the statistical support for the branches in the phylogeny, 1000 bootstrap replicates of the data were analyzed. Sequence identity values for atpD-dnaK-gyrB-rpoB concatenation were calculated using BioEdit software (Hall 2011) based on the multiple alignment constructed in MEGA7.

\section{Results and discussion}

\section{Phenotypic properties of $L$. nigricans rhizobia}

A total of 48 bacterial strains, including 33 L. nigricans symbionts and 15 reference strains, representing different species of the genera: Bradyrhizobium, Ensifer, Mesorhizobium, and Rhizobium were analyzed for 86 phenotypic properties. Table 1 presents some physiological and metabolic properties of the tested bacteria. In Supplementary Table S3, the results of all 86 characteristics are shown. The growth temperature range for the black broom rhizobia was determined to be between 13 and $3{ }^{\circ} \mathrm{C}$ with an optimal temperature of $28-30^{\circ} \mathrm{C}$, typical for most rhizobia. All L. nigricans symbionts, likewise the reference Bradyrhizobium species, grew at $\mathrm{pH} 5-8$. No strain tolerated $\mathrm{pH} 4$. Forty-five percent of the strains were able to grow at $\mathrm{pH} 9$ and $21 \%$ grew even at $\mathrm{pH} 10$. The black broom rhizobia were able to grow on YEM medium with 0.5 and $1 \% \mathrm{NaCl}$. Most of them tolerated $2 \%$ sodium chloride and $32 \%$ of the studied isolates tolerated $3 \% \mathrm{NaCl}$, in contrast to the genus Bradyrhizobium strains, which generally exhibit high sensitivity to salinity (Garrity et al. 2005). The L. nigricans symbionts were slow-growing rhizobia with generation time $\sim 6 \mathrm{~h}$ in YEM broth at $28^{\circ} \mathrm{C}$. Such a doubling time is characteristic for the strains of the genus Bradyrhizobium (van Berkum and Eardly 1998). Tests for assimilation of different compounds as sole carbon and nitrogen sources are commonly used in taxonomic studies of rhizobia. In our experiments, 25 different carbon-containing compounds were tested as sole sources of carbon for bacteria. All the tested isolates utilized 12 of the 25 studied carbon sources, i.e., L-alanine, Larginine, dextrin, mannitol, glycerol, sucrose, Tween-20, D-fructose, D-galactose, insulin, D-xylose, and sodium tartrate. The other carbon compounds served as growth substrates for only some bacteria studied (Table 1). In YEM medium with mannitol as a sole carbon source, black broom symbionts synthesized acid products similar to Rhizobium, Ensifer, and Mesorhizobium species strains (Garrity et al. 2005; Gnat et al. 2014). Most of the tested strains did not utilize disaccharides such as maltose and trehalose similar to slow-growing bradyrhizobia, which generally do not have disaccharide uptake systems (Glenn and Dilworth 1981; Elkan 1992). However, most of them exhibited good growth on lactose and sucrose.

Of the 21 nitrogen sources tested, only DL-ornithine was not utilized by all the L. nigricans symbionts, whereas 81 and $79 \%$ of the bacteria did not utilize L-lysine and sodium hippurate, respectively. The relevant phenotypic traits that differentiated the $L$. nigricans nodulators and the reference Bradyrhizobium species are listed in Table 1. An important taxonomic criterion used in differentiation of fast-growing 
Table 1 Some phenotypic characteristics of Lembotropis nigricans root nodule isolates and reference Bradyrhizobium strains

\begin{tabular}{|c|c|c|c|c|c|c|}
\hline Characteristics & $\begin{array}{l}\text { Lembotropis } \\
\text { nigricans } \\
\text { isolates }\left(n^{\mathrm{a}}=33\right)\end{array}$ & $\begin{array}{l}\text { Bradyrhizobium } \\
\text { elkanii USDA } \\
76^{\mathrm{T}}(n=1)\end{array}$ & $\begin{array}{l}\text { Bradyrhizobium } \\
\text { liaoningense USDA } \\
3622^{\mathrm{T}}(n=1)\end{array}$ & $\begin{array}{l}\text { Bradyrhizobium } \\
\text { yuanmingense CCBAU } \\
10071^{\mathrm{T}}(n=1)\end{array}$ & $\begin{array}{l}\text { Bradyrhizobium } \\
\text { diazoefficiens USDA } \\
110^{\mathrm{T}}(n=1)\end{array}$ & $\begin{array}{l}\text { Bradyrhizobium } \\
\text { japonicum USDA } \\
6^{\mathrm{T}}(n=1)\end{array}$ \\
\hline
\end{tabular}

Carbon sources used

\begin{tabular}{|c|c|}
\hline D-Arabinose & $+^{\mathrm{b}}(24)^{\mathrm{c}}$ \\
\hline D-Cellobiose & $+(21)$ \\
\hline D-Glucose & $+(27)$ \\
\hline D-Raffinose & $+(9)$ \\
\hline D-Trehalose & $+(4)$ \\
\hline D-Xylose & $+(33)$ \\
\hline Dextrin & $+(33)$ \\
\hline Inulin & $+(33)$ \\
\hline Lactose & $+(27)$ \\
\hline L-Alanine & $+(33)$ \\
\hline L-Arginine & $+(33)$ \\
\hline L-Asparagine & $+(24)$ \\
\hline L-Glutamine & $+(29)$ \\
\hline L-Lysine & $+(14)$ \\
\hline L-Rhamnose & $+(14)$ \\
\hline L-Tyrosine & $+(29)$ \\
\hline Maltose & $+(9)$ \\
\hline Salicin & $+(21)$ \\
\hline Sodium citrate & $+(24)$ \\
\hline $\begin{array}{l}\text { Sodium } \\
\text { hippurate }\end{array}$ & $+(4)$ \\
\hline Starch & $+(24)$ \\
\hline
\end{tabular}

Nitrogen sources used

\begin{tabular}{|c|c|}
\hline DL-Isoleucine & $+(30)$ \\
\hline L-Glutamic acid & $+(33)$ \\
\hline L-Lysine & $+(6)$ \\
\hline L-Phenylalanine & $+(29)$ \\
\hline L-Serine & $+(30)$ \\
\hline $\begin{array}{l}\text { Sodium } \\
\text { hippurate }\end{array}$ & $+(7)$ \\
\hline Sodium nitrate & $+(31)$ \\
\hline \multicolumn{2}{|l|}{ Resistant to } \\
\hline pH 9.0 & $+(15)$ \\
\hline pH 10.0 & $+(7)$ \\
\hline $1.0 \% \mathrm{NaCl}$ & $+(32)$ \\
\hline $3.0 \% \mathrm{NaCl}$ & $+(11)$ \\
\hline $\begin{array}{l}\text { Auramine } \\
0.05 \mu \mathrm{g} \mathrm{ml}-1\end{array}$ & $+(23)$ \\
\hline $\begin{array}{l}\text { Crystal violet } \\
0.1 \mu \mathrm{g} \mathrm{ml}^{-1}\end{array}$ & $+(2)$ \\
\hline $\begin{array}{l}\text { Methyl green } \\
0.13 \mu \mathrm{g} \mathrm{ml}\end{array}$ & $+(5)$ \\
\hline $\begin{array}{l}\text { Neutral red } \\
0.2 \mu \mathrm{g} \mathrm{ml}^{-1}\end{array}$ & $+(24)$ \\
\hline $\begin{array}{l}\text { Ampicillin } \\
\qquad 100 \mu \mathrm{g} \mathrm{ml}^{-1}\end{array}$ & $+(22)$ \\
\hline $\begin{array}{l}\text { Ampicillin } \\
200 \mu \mathrm{g} \mathrm{ml}^{-1}\end{array}$ & $+(13)$ \\
\hline $\begin{array}{l}\text { Rifampicin } \\
20 \mu \mathrm{g} \mathrm{ml}\end{array}$ & $+(28)$ \\
\hline
\end{tabular}


Table 1 (continued)

\begin{tabular}{|c|c|c|c|c|c|c|}
\hline Characteristics & $\begin{array}{l}\text { Lembotropis } \\
\text { nigricans } \\
\text { isolates }\left(n^{\mathrm{a}}=33\right)\end{array}$ & $\begin{array}{l}\text { Bradyrhizobium } \\
\text { elkanii USDA } \\
76^{\mathrm{T}}(n=1)\end{array}$ & $\begin{array}{l}\text { Bradyrhizobium } \\
\text { liaoningense USDA } \\
3622^{\mathrm{T}}(n=1)\end{array}$ & $\begin{array}{l}\text { Bradyrhizobium } \\
\text { yuanmingense CCBAU } \\
10071^{\mathrm{T}}(n=1)\end{array}$ & $\begin{array}{l}\text { Bradyrhizobium } \\
\text { diazoefficiens USDA } \\
110^{\mathrm{T}}(n=1)\end{array}$ & $\begin{array}{l}\text { Bradyrhizobium } \\
\text { japonicum USDA } \\
6^{\mathrm{T}}(n=1)\end{array}$ \\
\hline $\begin{array}{l}\text { Rifampicin } \\
200 \mu \mathrm{g} \mathrm{ml}^{-1}\end{array}$ & $+(12)$ & - & - & - & + & + \\
\hline $\begin{array}{l}\text { Streptomycin } \\
10 \mu \mathrm{g} \mathrm{ml}^{-1}\end{array}$ & $+(31)$ & + & + & + & + & + \\
\hline $\begin{array}{l}\text { Streptomycin } \\
200 \mu \mathrm{g} \mathrm{ml}^{-1}\end{array}$ & $+(13)$ & + & - & - & - & - \\
\hline $\begin{array}{l}\text { Tetracycline } \\
10 \mu \mathrm{g} \mathrm{ml}^{-1}\end{array}$ & $+(30)$ & + & + & + & + & + \\
\hline $\begin{array}{l}\text { Tetracycline } \\
40 \mu \mathrm{g} \mathrm{ml}^{-1}\end{array}$ & $+(3)$ & + & - & - & - & - \\
\hline
\end{tabular}

from slow-growing rhizobia is their tolerance to antibiotics (Elkan 1992). The black broom nodule isolates showed rather high tolerance to the tested antibiotics, similar to the Bradyrhizobium species (Kalita and Małek 2004). Most of them were resistant to ampicillin $\left(100 \mu \mathrm{g} \mathrm{ml}^{-1}\right)$, rifampicin $\left(20 \mu \mathrm{g} \mathrm{ml}^{-1}\right)$, streptomycin $\left(10 \mu \mathrm{g} \mathrm{ml}^{-1}\right)$, and tetracycline $\left(10 \mu \mathrm{g} \mathrm{ml}^{-1}\right)$. All of them were able to grow in the medium supplemented with acridine orange $(0.013 \%)$, crystal violet $(0.013 \%)$, methyl red $(0.05 \%)$, methyl green $(0.065 \%)$, neutral red $(0.1 \%)$, nigrosine $(0.5 \%)$, and safranin $(0.2 \%)$. Rhizobia specific to L. nigricans were highly homogeneous in enzyme activities (except catalase and phosphatase) and all of them hydrolyzed urea, reduced nitrate, produced active cytochrome oxidase, and exhibited evident alkaline reaction in the litmus milk test.

The phenotypic properties of the L. nigricans rhizobia and the reference strains representing the genera Bradyrhizobium, Ensifer, Mesorhizobium, and Rhizobium were subjected to numerical analysis with the use of the NTSYSpc software. The resulting dendrogram is shown in Fig. 1. The complete binary matrix table used for the numerical analysis is available as Supplementary Table 3. On the basis of the cluster analysis, all strains included into analysis formed two phena at the similarity coefficient level of 0.71 . Phenon I included bacteria of the genera Rhizobium, Ensifer, and Mesorhizobium. Phenon II contained slow-growing strains of the genus Bradyrhizobium and L. nigricans symbionts, which formed a separate subgroup at a similarity coefficient of 0.82 . The results presented in the dendrogram indicate that the slow-growing black broom rhizobia belong to the genus Bradyrhizobium. The high level of phenotypic diversity of the $L$. nigricans symbionts determined by the numerical analysis may facilitate their survival in changing environmental conditions in which these bacteria naturally live.

\section{BOX-PCR and AFLP analysis}

In recent years, many methods have been developed for molecular typing and assessing genomic heterogeneity of bacteria mainly within species or within closely related species. One of the best known genome fingerprinting techniques based on polymerase chain reaction (PCR) is BOX-PCR of highly conserved repetitive DNA sequences occurring naturally in bacterial genomes (Lupski and Weinstock 1992; Versalovic et al. 1994) as well as AFLP based on nucleotide changes within restriction sites and adjacent bases, which serve for primer annealing in the PCR reaction (Blears et al. 1998; Savelkoul et al. 1999). Both techniques generating DNA profiles specific to a given genome were used for analysis of the genomic diversity and genomic relationship of the 33 L. nigricans root nodule isolates. In the BOXA1R-PCR method, a 22-base oligonucleotide primer containing $68 \%$ of GC was applied. The use of the GC-rich primer in the BOXPCR method was associated with the high GC content of rhizobial genomes (Garrity et al. 2005) and helped to maximize the number of amplicons. In the PCR reaction with all black broom rhizobia, the BOXA1R primer produced DNA bands ranging in the size from 275 to 2134 nucleotides, with an average number of nine bands per strain. The DNA BOX patterns were used for cluster analysis and presentation of the genomic relationship in the form of a dendrogram (Fig. 2). In the generated dendrogram, the 33 L. nigricans symbionts were divided into three main clusters. In the first cluster, two strains (LN1 and LN14) were placed distinctly from the other bacteria. The second main cluster comprised 17 isolates with a DNA pattern similarity level from 71 to $100 \%$, whereas the third one encompassed 14 strains with a DNA pattern similarity level in the range from 82 to $100 \%$. The BOX-PCR method allowed identification of 27 genomotypes among the 33 black broom microsymbionts. Eleven strains belong to 5 clusters 


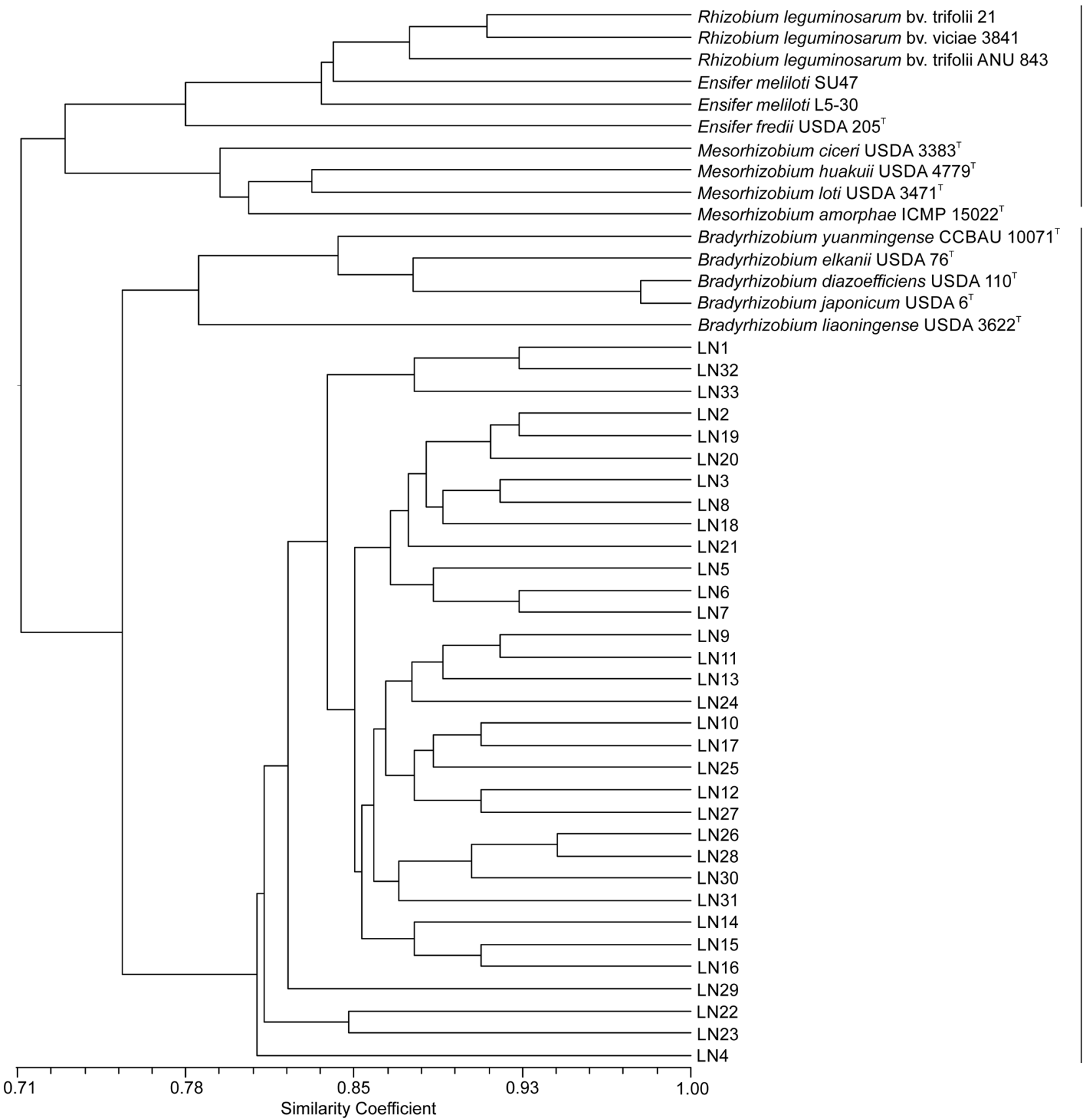

Fig. 1 UPGMA dendrogram showing phenotypic relationships among 33 Lembotropis nigricans root nodule isolates and reference strains

comprising at least two root nodule isolates sharing identical DNA profiles (Fig. 2).

To investigate the genomic diversity of the L. nigricans symbionts in greater detail, the AFLP technique was also used. Presently, bacteriologists frequently use this method in the assessment of genomic diversity both within species and across different bacterial populations (Aserse et al. 2012; Li et al. 2012; Xu et al. 2016). For fingerprinting the black broom rhizobial genomes and assessment of their genomic relationships with the AFLP method, Pst I endonuclease recognizing a GC-rich sequence 5'-CTGGAG-3' and the primer pair PstIGC with GC as arbitrary bases at the $3^{\prime}$ end were used. The
AFLP profiles of the bacteria studied contained from 1 to 19 DNA bands per strain and their size was from 184 to $1486 \mathrm{bp}$. On the basis of DNA banding profiles, it was possible to differentiate all black broom rhizobia except two strains, which exhibited identical genomic patterns in the AFLP method with the PsI-GC primer. The genomic relationships of L. nigricans symbionts based on AFLP fingerprinting data are presented in the dendrogram generated by UPGMA cluster analysis (Fig. 2). In this tree, the rhizobia studied were split into two major groups at a DNA similarity coefficient level of 0.55 . One cluster encompassed ten rhizobia, including two strains (LN22 and LN23) sharing identical DNA patterns. 
Fig. 2 Dendrograms based on (a) BOX-PCR and (b) AFLP data of 33 Lembotropis nigricans root nodule isolates. Nei and Li coefficient was used for similarity measure. UPGMA was used for clustering a BOX-PCR

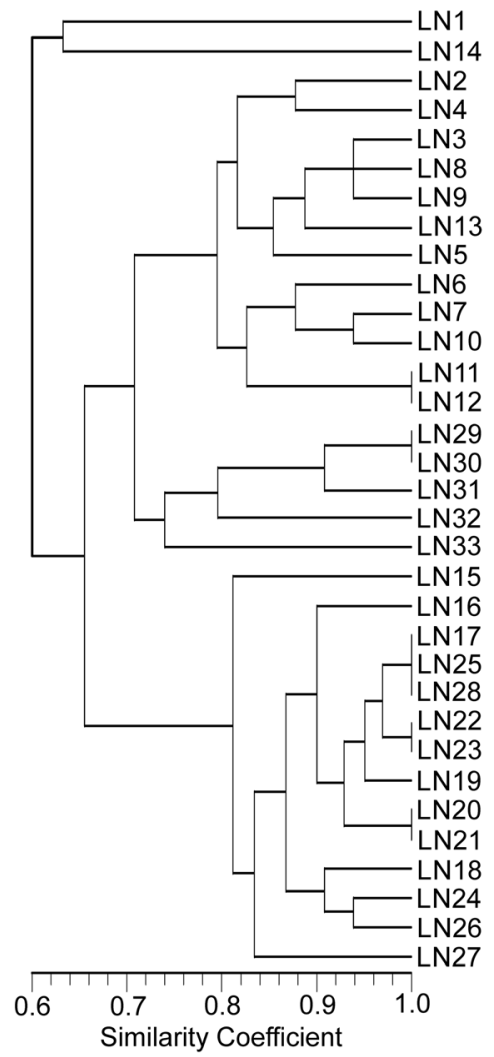

b AFLP

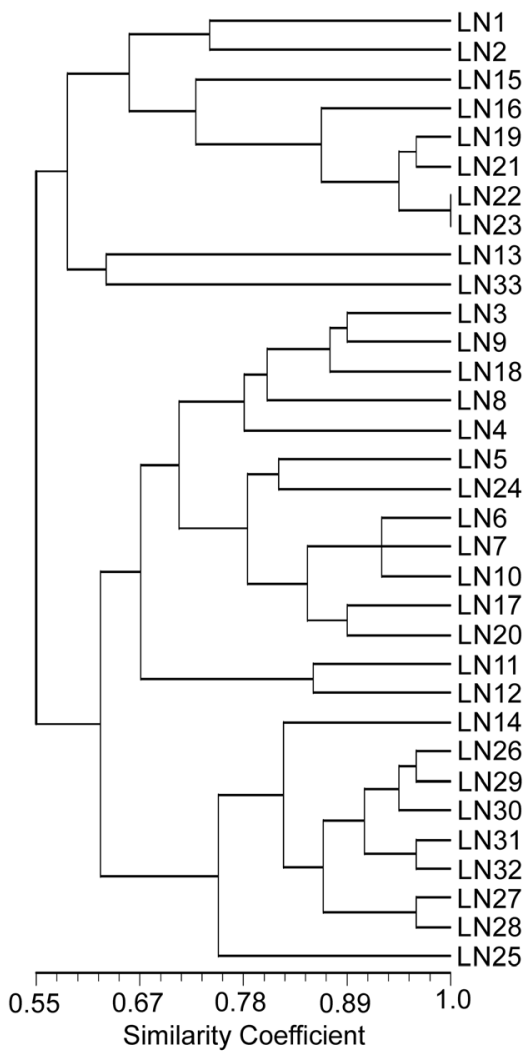

The other group comprised 23 strains separated into two genomically different subgroups at a similarity coefficient level of 0.62 . Genome heterogeneity of rhizobia is shaped by environmental factors and limited by the symbiotic interaction with the host plant. Our studies showed that the AFLP technique was superior to the BOX-PCR method in differentiating the $L$. nigricans symbionts and facilitated identification of 32 genomotypes among the 33 bacterial strains studied. We also showed that both these genome profiling techniques used offer a convenient way to choose the representative strains from each genomic group for further taxonomic studies, such as 16S rDNA and multilocus sequence analysis (MLSA).

\section{S rDNA sequence analysis}

Comparative analysis of $16 \mathrm{~S}$ rDNA sequences is widely used to study the taxonomic position of bacteria at the genus level and to depict bacterial phylogeny. It was demonstrated that a 16S rRNA gene sequence similarity lower than $98.7 \%$ suggests that bacterial strains belong to distinct species (Yarza et al. 2014). Analysis of 16S rRNA gene sequences has some difficulties in the case of Bradyrhizobium bacteria since many newly described bradyrhizobial species show $99.4 \%$ or higher $16 \mathrm{~S}$ rDNA sequence identity to the previously defined species of the genus Bradyrhizobium (Chahboune et al. 2012;
Guerrouj et al. 2013; Grönemeyer et al. 2017; Costa et al. 2018).

In order to clarify the genus position of the L. nigricans symbionts and investigate their evolutionary relationship with other bacteria of the genus Bradyrhizobium, the nearly fulllength $16 \mathrm{~S}$ rRNA encoding genes of 11 symbionts representing different phenotypic and genomic groups of black broom nodule isolates were amplified and sequenced. The 16S rDNA sequences of the studied rhizobia were aligned and compared with those of other nodule bacteria available in the GenBank database. The evolutionary distances between L. nigricans symbionts and reference bacteria representing the genus Bradyrhizobium were calculated from a $1228 \mathrm{bp}-$ long alignment and molecular phylogeny was reconstructed using the maximum likelihood method (ML). The level of sequence similarity between the $16 \mathrm{~S}$ rDNA of the black broom rhizobia and those of Bradyrhizobium ranged from 94.8 to $100 \%$. The L. nigricans rhizobia were most similar $(\geq 99.5 \%)$ in their $16 \mathrm{~S}$ rDNA sequences to $B$. japonicum USDA $6^{\mathrm{T}}, B$. canariense BTA- ${ }^{\mathrm{T}}$, B. lianingense USDA $3622^{\mathrm{T}}, B$. daqingense CCBAU $15774^{\mathrm{T}}$, and $B$. americanum CMVU44 ${ }^{\mathrm{T}}$. The $16 \mathrm{~S}$ rDNA sequences of the black broom nodule isolates shared $99.6-100 \%$ sequence identity. The 16S rDNA nucleotide sequences of strains LN1, LN2, LN10, LN11, LN20, LN30, and LN32 were identical to each other and to B. japonicum BGA-1. Interestingly, the $16 \mathrm{~S}$ 
Fig. 3 Maximum likelihood phylogenetic tree of $16 \mathrm{~S}$ rDNA sequences of Lembotropis nigricans root nodule isolates (shown in bold) and reference bradyrhizobia. Bootstrap values $\geq 50 \%$ are given at the branching points. The scale bar indicates the number of substitutions per site. GenBank accession numbers are given in parentheses

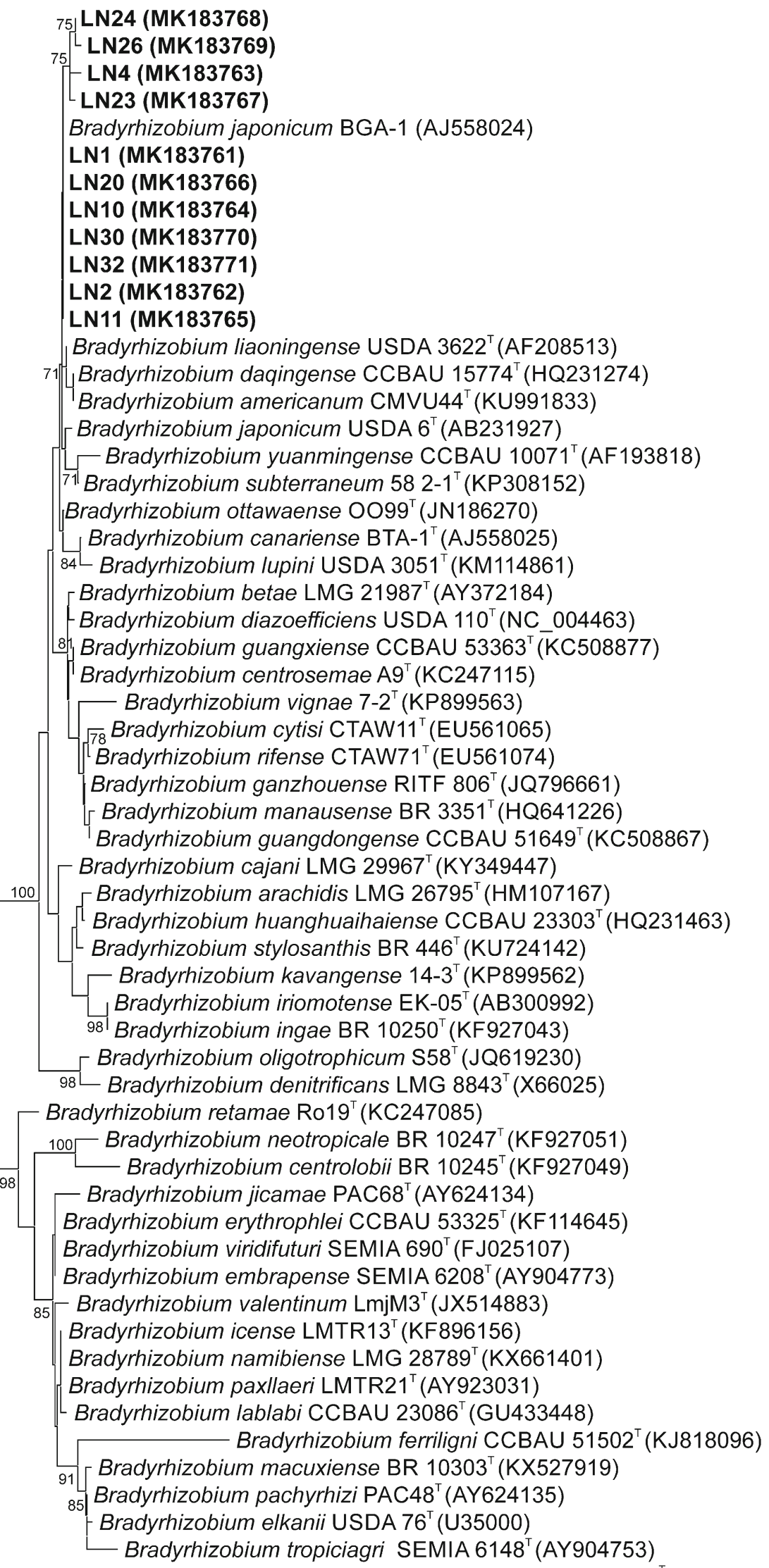


rDNA sequence of $B$. japonicum BGA-1 was different from that of $B$. japonicum USDA $6^{\mathrm{T}}$ at two nucleotide positions (99.8\% similarity) at which it was identical to B. liaoningense USDA $3622^{\mathrm{T}}$ (99.9\% sequence similarity). This observation clearly indicates a very low level of $16 \mathrm{~S}$ rRNA gene sequence heterogeneity among Bradyrhizobium species. It also suggests that $16 \mathrm{~S}$ rRNA as a molecular marker has serious limitations for species delineation. The results of comparative 16S rDNA sequence analysis confirmed those of the numerical analysis of phenotypic features (Fig. 1) and showed that the black broom rhizobia are members of the genus Bradyrhizobium species. The phylogenetic relatedness of the L. nigricans rhizobia with other nodule bacteria is presented in the form of a phylogram in Fig. 3. On the $16 \mathrm{~S}$ rDNA tree, the L. nigricans symbionts and reference Bradyrhizobium strains were divided into two distinct clusters with bootstrap values of $100 \%$ and $98 \%$. The cluster with $100 \%$ confidence encompasses all black broom rhizobia and 28 reference bradyrhizobia. The B. elkanii, B. erythrophlei, $B$. valentinum, and $B$. lablabi species were assigned to the other group. The same splitting of the Bradyrhizobium species was previously described for phylogenetic trees reconstructed using 16S rDNA sequences (Menna et al. 2009; Delamuta et al. 2012; Kalita and Małek 2017). The pattern of branching on the phylogram shown in Fig. 3 suggests a close relationship of the studied black broom rhizobia with B. japonicum BGA1. However, due to the high level of $16 \mathrm{~S}$ rRNA sequence conservation between the Bradyrhizobium species described above, where two strains of different species can have more similar 16S rDNA nucleotide sequences than two strains of the same species, additional analyses were used to determine the species position of the $L$. nigricans root isolates.

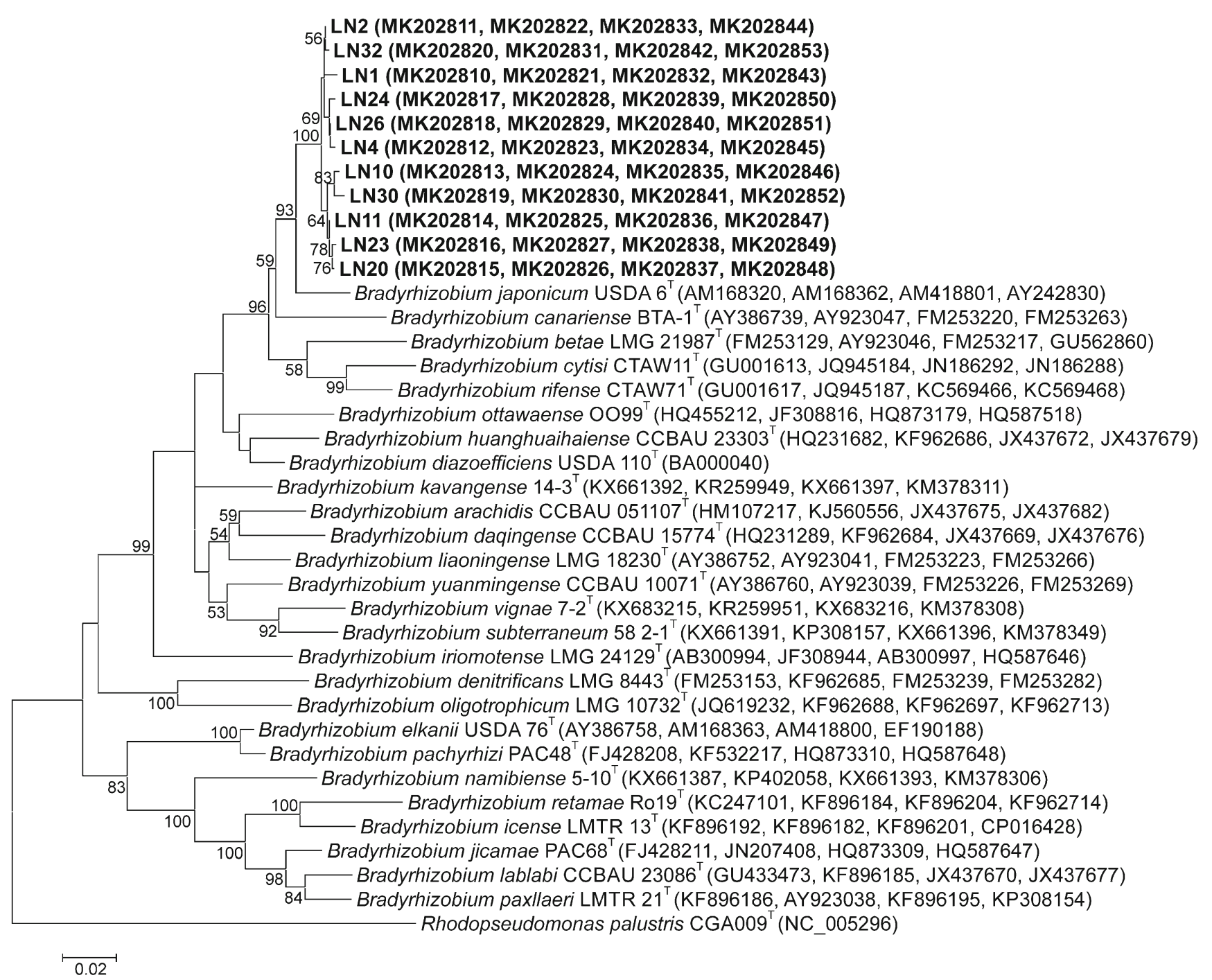

Fig. 4 Maximum likelihood phylogenetic tree of concatenated atpD, dnaK, gyrB, and rpoB gene sequences of Lembotropis nigricans root nodule isolates (shown in bold) and reference bradyrhizobia. Bootstrap values $\geq 50 \%$ are given at branching points. The scale bar indicates the number of substitution per site. GenBank accession numbers are given in parentheses 


\section{Analysis of concatenated atpD-dnaK-gyrB-rpoB gene sequences}

Phylogenetic analysis was carried out using concatenated nucleotide sequences of four housekeeping genes: atpD, dnaK, $g y r B$, and $r p o B$. Housekeeping genes have been widely used in many studies of Bradyrhizobium bacteria to delineate closely related species (Vinuesa et al. 2005; Rivas et al. 2009; Chahboune et al. 2012; Delamuta et al. 2013; Kalita and Małek 2017). Although the protein-encoding genes used in the phylogenetic analysis of Bradyrhizobium bacteria display a considerably higher level of sequence diversity compared to $16 \mathrm{~S}$ rDNA, no threshold value that could be used for species demarcation has ever been proposed as it was done in case of ANI (average nucleotide identity), where it is widely accepted that $\geq 95 \%$ ANI represents an accurate threshold for delineating almost all currently named prokaryotic species (Chun et al. 2018; Jain et al. 2018).

The black broom rhizobia shared from 98.9 to $99.8 \%$ similarity of concatenated sequences of the four studied genes. The $L$. nigricans strains were most similar to B. japonicum USDA $6^{\mathrm{T}}(96.7$ to $97.2 \%)$. The identity of the analyzed sequences of L. nigricans bradyrhizobia to other Bradyrhizobium species ranged from $87.7 \%$ in the case of B. retamae Ro $19^{\mathrm{T}}$ to $95.3 \%$ for $B$. canariense $\mathrm{BTA}-1^{\mathrm{T}}$. It should be noticed that the highest similarity value of L. nigricans microsymbionts to B. japonicum USDA $6^{\mathrm{T}}$ $(97.2 \%)$ is lower than the sequence similarity between B. elkanii USDA $76^{\mathrm{T}}$ and B. pachyrhizi PAC $48^{\mathrm{T}}(98.4 \%)$. Moreover, the lowest sequence similarity estimated between B. japonicum USDA $6^{\mathrm{T}}$ and black broom bradyrhizobia (96.7\%) overlaps the atpD-dnaK-gyrB-rpoB sequence similarity of $B$. paxllaeri LMTR $21^{\mathrm{T}}$ and $B$. lablabi CCBAU23086 ${ }^{\mathrm{T}}(96.7 \%)$. These data indicate that there is no clear gap for interspecific sequence similarity values since, as demonstrated above, two species can exhibit higher identity than strains belonging to a single species. Similar findings were also reported in other studies of the genus Bradyrhizobium using different sets of housekeeping genes as molecular markers (Menna et al. 2009; Rivas et al. 2009; Zhang et al. 2012). Regardless of this observation, which could be considered as a drawback of the multilocus sequence analysis (MLSA) in prokaryotic taxonomy, the bacterial strains on the phylogenetic tree reconstructed using concatenated sequences of several genes form clusters supporting their species affiliation. As can be seen on the phylogram in Fig. 4, all the black broom bradyrhizobia form a common group with $B$. japonicum USDA $6^{\mathrm{T}}$. This grouping better reflects the evolutionary relationship of the studied isolates with this reference species than analysis based solely on the $16 \mathrm{~S}$ rDNA sequences. Since there is no information available in the public databases on the $g y r B$ gene sequence of B. japonicum BGA-1, this strain was not used in our multilocus sequence analysis based on four markers. Nevertheless, the phylogram constructed using concatenation of three gene sequences ( $a t p D$-dnaK-rpoB) strongly supports the grouping of the L. nigricans isolates and B. japonicum BGA-1 on the $16 \mathrm{~S}$ rRNA phylogenetic tree (Supplementary Figure S4). It also supports our conclusion that L. nigricans microsymbionts belong to B. japonicum.

All the results presented in this study clearly indicate that L. nigricans, a plant of tribe Genisteae which has not been previously studied for bacteria inhabiting its root nodules, is infected by strains belonging to B. japonicum species. The present study supports our previous results and data reported by other authors that root nodules of the tribe Genisteae plants are mainly inhabited by bacteria of the genus Bradyrhizobium (Kalita and Małek 2010; Stępkowski et al. 2011; Kalita and Małek 2017; Stępkowski et al. 2018).

Funding The study was conducted by the research fund of Faculty of Biotechnology and Biology, Maria Curie-Skłodowska University, Lublin, Poland.

Open Access This article is distributed under the terms of the Creative Commons Attribution 4.0 International License (http:// creativecommons.org/licenses/by/4.0/), which permits unrestricted use, distribution, and reproduction in any medium, provided you give appropriate credit to the original author(s) and the source, provide a link to the Creative Commons license, and indicate if changes were made.

\section{References}

Altschul SF, Gish W, Miller W, Myers EW, Lipman DJ (1990) Basic local alignment search tool. J Mol Biol 215:403-410

Aserse AA, Räsänen LA, Assefa F, Hailemariam A, Lindström K (2012) Phylogeny and genetic diversity of native rhizobia nodulating common bean (Phaseolus vulgaris L.) in Ethiopia. Syst Appl Microbiol 35:120-131

Blears MJ, De Grandis SA, Le H, Trevors JT (1998) Amplified fragment length polymorphism (AFLP): a review of the procedure and its application. J Ind Microbiol Biotechnol 8:99-114

Cardoso D, Pennington RT, de Queiroz LP, Boatwright JS, Van Wyk B-E, Wojciechowski MF, Lavin M (2013) Reconstructing the deepbranching relationships of the papilionoid legumes. S Afr J Bot 89:58-75

Chahboune R, Carro L, Peix A, Ramírez-Bahena MH, Barrijal S, Velázquez E, Bedmar EJ (2012) Bradyrhizobium rifense sp. nov. isolated from effective nodules of Cytisus villosus grown in the Moroccan Rif. Syst Appl Microbiol 35:302-305

Chidebe IN, Jaiswal SK, Dakora FD (2018) Distribution and phylogeny of microsymbionts associated with cowpea (Vigna unguiculata) nodulation in three agroecological regions of Mozambique. Appl Environ Microbiol 84:e1712-e01717

Chun J, Oren A, Ventosa A, Christensen H, Arahal DR, da Costa MS, Rooney AP, Yi H, Xu XW, De Meyer S, Trujillo ME (2018) Proposed minimal standards for the use of genome data for the taxonomy of prokaryotes. Int J Syst Evol Microbiol 68:461-466 
Costa EM, Guimarães AA, Carvalho ST, Rodrigues LT, Ribeiro PRA, Lebbe L, Willems A, Moreira FMS (2018) Bradyrhizobium forestalis sp. nov., an efficient nitrogen-fixing bacterium isolated from nodules of forest legume species in the Amazon. Arch Microbiol 200:743-752

Darriba D, Taboada GL, Doallo R, Posada D (2012) jModelTest 2: more models, new heuristics and parallel computing. Nat Methods 9:772

Delamuta JR, Ribeiro RA, Menna P, Bangel EV, Hungria M (2012) Multilocus sequence analysis (MLSA) of Bradyrhizobium strains: revealing high diversity of tropical diazotrophic symbiotic bacteria. Braz J Microbiol 43:698-710

Delamuta JR, Ribeiro RA, Ormeño-Orrillo E, Melo IS, Martínez-Romero E, Hungria M (2013) Polyphasic evidence supporting the reclassification of Bradyrhizobium japonicum group Ia strains as Bradyrhizobium diazoefficiens sp. nov. Int J Syst Evol Microbiol 63:3342-3351

Elkan GH (1992) Taxonomy of the rhizobia. Can J Microbiol 38:446450

Garrity GM, Bell JA, Lilburn T (2005) Class I. Alphaproteobacteria class. nov. In: Brenner DJ, Kreig NR, Staley JT (eds) Bergey's manual of systematic bacteriology Vol. 2 Part C. The alpha-, beta-, delta-, and epsilonproteobacteria, 2nd edn., Springer, pp 1-547

Gaunt MW, Turner SL, Rigottier-Gois L, Lloyd-Macgilp SA, Young JPW (2001) Phylogenies of atpD and recA support the small subunit rRNA-based classification of rhizobia. Int J Syst Evol Microbiol 51:2037-2048

Glenn AR, Dilworth MJ (1981) The uptake and hydrolysis of disaccharides by fast- and slow-growing species of Rhizobium. Arch Microbiol 129:233-239

Gnat S, Wójcik M, Wdowiak-Wróbel S, Kalita M, Ptaszyńska A, Małek W (2014) Phenotypic characterization of Astragalus glycyphyllos symbionts and their phylogeny based on the 16S rDNA sequences and RFLP of 16S rRNA gene. Antonie Van Leeuwenhoek 105: $1033-1048$

Gnat S, Małek W, Oleńska E, Trościańczyk A, Wdowiak-Wróbel S, Kalita M, Wójcik M (2015) Insight into the genomic diversity and relationship of Astragalus glycyphyllos symbionts by RAPD, ERICPCR, and AFLP fingerprinting. J Appl Genet 56:551-554

Grönemeyer JL, Bünger W, Reinhold-Hurek B (2017) Bradyrhizobium namibiense sp. nov., a symbiotic nitrogen-fixing bacterium from root nodules of Lablab purpureus, hyacinth bean, in Namibia. Int J Syst Evol Microbiol 67:4884-4891

Guerrouj K, Ruíz-Díez B, Chahboune R, Ramírez-Bahena MH, Abdelmoumen H, Quiñones MA, El Idrissi MM, Velázquez E, Fernández-Pascual M, Bedmar EJ, Peix A (2013) Definition of a novel symbiovar (sv. retamae) within Bradyrhizobium retamae sp. nov., nodulating Retama sphaerocarpa and Retama monosperma. Syst Appl Microbiol 36:218-223

Hall T (2011) BioEdit: an important software for molecular biology. GERF Bull Biosci 2:60-61

Huang CT, Hish KT, Wang CN, Liu CT, Kao WY (2018) Phylogenetic analyses of Bradyrhizobium symbionts associated with invasive Crotalaria zanzibarica and its coexisting legumes in Taiwan. Syst Appl Microbiol 41:619-628

Jain C, Rodriguez LMR, Phillippy AM, Konstantinidis KT, Aluru S (2018) High throughput ANI analysis of 90K prokaryotic genomes reveals clear species boundaries. Nat Commun 9:5114

Kalita M, Małek W (2004) Phenotypic and genomic characteristics of rhizobia isolated from Genista tinctoria root nodules. Syst Appl Microbiol 27:707-715

Kalita M, Małek W (2006) Application of the AFLP method to differentiate Genista tinctoria microsymbionts. J Gen Appl Microbiol 52: 321-328

Kalita M, Małek W (2010) Genista tinctoria microsymbionts from Poland are new members of Bradyrhizobium japonicum bv. genistearum. Syst Appl Microbiol 33:252-259
Kalita M, Małek W (2017) Molecular phylogeny of Bradyrhizobium bacteria isolated from root nodules of tribe Genisteae plants growing in southeast Poland. Syst Appl Microbiol 40:482-491

Kumar S, Stecher G, Tamura K (2016) MEGA7: molecular evolutionary genetics analysis version 7.0 for bigger datasets. Mol Biol Evol 33: 1870-1874

Li L, Sinkko H, Montonen L, Wei G, Lindström K, Räsänen LA (2012) Biogeography of symbiotic and other endophytic bacteria isolated from medicinal Glycyrrhiza species in China. FEMS Microbiol Ecol 79:46-68

Liu XY, Wu W, Wang ET, Zhang B, Macdermott J, Chen WX (2011) Phylogenetic relationships and diversity of b-rhizobia associated with Mimosa species grown in Sishuangbanna, China. Int J Syst Evol Microbiol 61:334-342

Łotocka B, Kopcińska J, Skalniak M (2012) Review article: the meristem in indeterminate root nodules of Faboideae. Symbiosis 58:63-72

Lupski JR, Weinstock GM (1992) Short, interspersed repetitive DNA sequences in prokaryotic genomes. J Bacteriol 174:4525-4529

Menna P, Barcellos FG, Hungria M (2009) Phylogeny and taxonomy of a diverse collection of Bradyrhizobium strains based on multilocus sequence analysis of the 16S rRNA gene, ITS region and glnII, recA, atpD and dnaK genes. Int J Syst Evol Microbiol 59:2934 2950

Nei M, Li WH (1979) Mathematical model for studying genetic variation in terms of restriction endonucleases. Proc Natl Acad Sci U S A 76: $5269-5273$

Petrowicz M (1981) Lembotropis nigricans (L.) Griseb. in Poland. Ann UMCS Sect C 36:193-215

Pitcher DG, Saunders NA, Owen RJ (1989) Rapid extraction of bacterial genomic DNA with guanidium thiocyanate. Lett Appl Microbiol 8: $151-156$

Rivas R, Martens M, de Lajudie P, Willems A (2009) Multilocus sequence analysis of the genus Bradyrhizobium. Syst Appl Microbiol 32:101-110

Savelkoul PHM, Aarts HJM, de Haas J, Dijkshoorn L, Dium B, Otsen M, Rademaker JLW, Schools L, Lenstra JA (1999) Amplified-fragment length polymorphism analysis: the state of an art. J Clin Microbiol 37:3083-3091

Sneath PHA, Sokal RR (1973) Numerical taxonomy. Freeman, San Francisco

Stępkowski T, Czaplińska M, Miedzińska K, Moulin L (2003) The variable part of the $d n a K$ gene as an alternative marker for phylogenetic studies of rhizobia and related alpha Proteobacteria. Syst Appl Microbiol 26:483-494

Stepkowski T, Żak M, Moulin L, Króliczak J, Golińska B, Narożna D, Safronowa VI, Mądrzak CJ (2011) Bradyrhizobium canariense and Bradyrhizobium japonicum are the two dominant rhizobium species in root nodules of lupin and serradella plants growing in Europe. Syst Appl Microbiol 34:368-375

Stẹpkowski T, Banasiewicz J, Granada CE, Andrews M, Passaglia LMP (2018) Phylogeny and phylogeography of rhizobial symbionts nodulating legumes of the tribe Genisteae. Genes 9:163. https:// doi.org/10.3390/genes 9030163

Tyrka M (2002) A simplified AFLP method for fingerprinting of common wheat (Triticum aestivum L.) cultivars. J Appl Genet 43:131143

van Berkum P, Eardly BD (1998) Molecular evolutionary systematics of the Rhizobiaceae. In: Spaink HP, Kondorosi A, Hooykaas PJJ (eds) The Rhizobiaceae. Springer. https://doi.org/10.1007/978-94-0115060-6

Vandamme P, Peeters C (2014) Time to revisit polyphasic taxonomy. Antonie Van Leeuwenhoek 106:57-65

Versalovic J, Schneider M, de Bruijn FJ, Lupski JR (1994) Genomic fingerprinting of bacteria using repetitive sequence-based polymerase chain reaction. Methods Mol Cell Biol 5:25-40 
Vinuesa P, Rademaker JLW, de Bruijn FJ, Werner D (1998) Genotypic characterization of Bradyrhizobium strains nodulating endemic woody legumes of the Canary Islands by PCR-restriction fragment length polymorphism analysis of genes encoding 16S rRNA [16S rDNA] and 16S-23S rRNA intergenic spacers, repetitive extragenic palindromic PCR genomic fingerprinting, and partial 16S rRNA sequencing. Appl Environ Microbiol 64:2096-2104

Vinuesa P, Silva C, Werner D, Martinez-Romero E (2005) Population genetics and phylogenetic inference in bacterial molecular systematics: the roles of migration and recombination in Bradyrhizobium species cohesion and delineation. Mol Phylogenet Evol 34:29-54

Wdowiak S, Małek W (2000) Numerical analysis of Astragalus cicer microsymbionts. Curr Microbiol 41:142-148

Wdowiak-Wróbel S, Marek-Kozaczuk M, Kalita M, Karaś M, Wójcik M, Małek W (2017) Diversity and plant growth promoting properties of rhizobia isolated from root nodules of Ononis arvensis. Antonie Van Leeuwenhoek 110:1087-1103

Xu KW, Zou L, Penttinen P, Zeng X, Liu M, Zhao K, Chen C, Chen YX, Zhang X (2016) Diversity and phylogeny of rhizobia associated with Desmodium spp. in Panxi, Sichuan, China. Syst Appl Microbiol 39:33-40

Yarza P, Yilmaz P, Pruesse E, Glöckner FO, Ludwig W, Schleifer K-H, Whitman WB, Euzéby J, Amann R, Rosselló-Móra R (2014) Uniting the classification of cultured and uncultured bacteria and archaea using 16S rRNA gene sequences. Nat Rev Microbiol 12: 635-645

Young JPW, Downer HL, Eardly BD (1991) Phylogeny of the phototropic Rhizobium strain BTAi 1 by polymerase chain reaction-based sequencing of a 16S rRNA gene segment. J Bacteriol 173:22712277

Zhang YM, Tian CF, Sui XH, Chen WF, Chen WX (2012) Robust markers reflecting phylogeny and taxonomy of rhizobia. PLoS One 7:e44936

Publisher's note Springer Nature remains neutral with regard to jurisdictional claims in published maps and institutional affiliations. 